Lorenz Nigst: “"Entering a gigantic maze:' The ambivalent presence of previous-life memories in Druze discourse," in: Social Compass, Vol. 66, Issue 2 (2019), pp. 273-288.

https://journals.sagepub.com/doi/10.1177/0037768619833317

Article first published online: March 27, 2019

Issue published: June 1, 2019 


\title{
'Entering a gigantic maze:' The ambivalent presence of previous-life memories in Druze discourse
}

\section{Lorenz NIGST}

Austrian Academy of Sciences, Austria

\begin{abstract}
According to the Druze notion of transmigration (taqammus), whenever someone dies, his or her soul moves into the body of a newborn Druze of the same sex. While this makes the Druze feel that they belong together in a more fundamental way because they are 'born in each other's houses' (Oppenheimer), it is more ambivalent the moment children start to 'speak' about previous lives in another family. Allowing the 'return' of someone lost to death and potentially bringing two such houses in closer relation, 'speaking' also requires coming to terms with conflicting belonging.
\end{abstract}

Keywords Druze, transmigration ; taqammuṣ; nuțq, previous-life memories

\section{Résumé}

Selon la notion druze de transmigration (taqammuss), quand une personne meurt, son âme entre dans le corps d'un nouveau-né druze du même sexe. Bien que cela donne aux druzes le sentiment d'appartenir à une communauté plus fondamentale parce qu'ils sont « nés dans la maison de l'autre « (Oppenheimer), la situation devient plus ambivalente quand enfants commencent à «parler » de leurs vies antérieures, ce qui rapproche potentiellement ces deux maisons l'une de l'autre 


\section{Corresponding author:}

Lorenz Nigst, Phonogrammarchiv, Austrian Academy of Sciences, Liebiggasse 5, 1010 Vienna, Austria.

Email: lorenz.nigst@oeaw.ac.at

\section{Introduction}

'It is difficult to understand how a toddler could want to see his children.' 'He is my brother, and he is not my brother at the same time!' 'His grandmother is a good deal younger than him.' ‘ Families do not want their children to belong to another family in addition to themselves.' 'I would not want to know who I was in a previous life.' Alongside other similar statements, these were documented during the course of a research project focused on the Druze ${ }^{1}$ belief in taqammus or the 'transmigration of the souls' / 'rebirth.' The above statements make sense through this idea that the soul migrates to a new body after death. More specifically, they reveal that in the Druze communities of the Middle East taqammus is not just the subject matter of abstract thoughts, but sometimes surfaces in the form of concrete cases, which are inextricably linked to a phenomenon termed 'speaking' (nutq) in Arabic where children start to 'speak' (nataqa) about a previous life. According to Druze discourse, this 'speaking' must be understood as a soul remembering elements of its former life and often the moment of death itself. Time and again, 'stories' (qisaș) are told about 'speaking' children ${ }^{2}$ within the range of 2-4 years who insist that they are someone else, maybe want to be with another family, or talk about how they died. As a rule, their previous lives came to an untimely or violent end, in which accidents, murder, or diseases abound. ${ }^{3}$ It is part of the Druze experience of taqammus that, sometimes and contingent on proof, such children 're-take' the unique place they occupied in their previous life. 
On the one hand, the notion that the soul migrates from body to body is attractive. It offers an answer to seeming inequalities through claiming that divine justice materializes across the boundaries of a single life-circuit. Or it explains that those lost to death in reality live on in the form of a different human being. In this context, the phenomenon of 'speaking' not only turns the central propositional content that 'souls migrate from body to body' into something 'palpable and real' ( 'shī māddī malmūs'), but, if reflected upon, also contains all sorts of moral lessons (' 'ibar mu 'ayyane'). ${ }^{4}$ From the emic perspective, not only does each case of 'speaking' corroborate anew that people are actually reborn and make visible who is reborn as who (e.g. Druze as Druze), but the cases also make particularly obvious that the (divine) logic of taqammus puts the things that matter in everyday-life into perspective, such as descent, economic interests, or rivalries over power (see Rivoal, 2000: 384-385). The Druze, for example, suggest that cases of 'speaking' do play a certain role in ending 'man-made' forms of conflict, including blood vengeance. ${ }^{5}$ It furthermore is not uncommon to hear that crimes were solved through 'speaking' children or reincarnated individuals in general, in the sense that, for example, a 'speaking' child named his or her murderer (see also Bennett, 1999: 113).

On the other hand, as interviews with Druze show, the phenomenon of 'speaking' is is more ambivalent the moment it affects concrete people. To begin with, one does not know where it will lead to, nor who or what will reappear if the case unfurls. In line with Pierre Bourdieu's observation that to reintroduce time is to reintroduce uncertainty (Bourdieu and Wacquant, 1992: 138), 'speaking' initially is pervaded with uncertainty and some people are afraid of the threatening quality of things unknown ( 'khōf min al-majhūl'). Even before it sets in, depending on how one is linked to the 'speaking' individual, 'speaking' may be a source of both hope and anxiety. More specifically, 'speaking' is ambivalent insofar as it promises to result in sociologically real relationships that link a 'previous' and a 'present' life. While this allows the 'return' of someone lost to death in different bodily form, it also is associated with difficulties, and the latter are often reckoned with, because this way one soul may become associated with two known places (the previous-life and the present-life place) at the same time. Concrete human 
beings and their families may thus be cast in characteristic forms of confusion, conflict, disorder, and not always pleasant or desired forms of proximity.

This article first explores the general Druze notion of transmigration and subsequently highlights difficulties that may arise if 'speaking' pushes transmigration to the level of concrete human beings with a unique place in the social world.

The empirical material on which it rests has been gathered through about 25 interviews in Lebanon in October 2016 and in Austria among Syrian Druze refugees between April 2016 and February 2017. ${ }^{6}$ Apart from three Christian women who were friends with our Lebanese interview partners, all interview partners were (non-religious) Druze, both male and female, ranging from their mid-twenties to their sixties. While in two instances, the reincarnated individuals told their own story, in most cases, individuals told about a reincarnated relative or friend, or cases from their locality. In several instances, the reincarnated individuals themselves declined to be interviewed. The interview partners, on which this article rests, do not comprise parents of 'speaking' children. ${ }^{7}$ Some families comprising a reincarnated individual knew the previous-life family, others did not. If relatives or friends recounted the case, they were almost all from the side of the reincarnated individual. Generally, people were asked to explain what taqammus was, whether they could recount cases, and what their own ideas regarding the phenomenon were. In several instances, our interview partners spontaneously tried to call people they knew, and the cases were told with the group of friends present; at other times, only the interview partner was present.

There is not a singular Druze stance on 'speaking.' Furthermore, 'speaking' may feel quite different depending on whether it has already taken place or led to relationships; it may be perceived differently throughout a person's life and depending on whether one belongs to the 'speaking' child or the person lost to death; it may be happy in one case, and not so in others; the social relationships established through 'speaking' may be both desired and a burden; etc. This article does not aspire to reconstruct any individual case, but seeks to construct an analytical framework through which this ambivalent presence may be better understood and to document how the ambivalent nature of the phenomenon reappears in statements of interview partners and 
to all appearances forms a part of the Druze discourse on transmigration. For this reason, it furthermore includes online material, in part recommended by interview partners, that attests to the discursive presence under scrutiny.

This article draws on both a solid body of research about the Druze and their theological thought (see e.g. de Smet, 2007; Firro, 2011), as well as on important anthropological studies that address transmigration in a Druze context (see e.g. Oppenheimer, 1980; Bennett 1999, 2006; Rivoal 2000, 2016; Armanet, 2011; Kastrinou, 2016). The phenomenon of 'speaking' furthermore has been the subject of psychology (see Dwairy, 2006) as well as of research in the vein of Ian Stevenson (see e.g. Stevenson and Haraldsson, 2003), which in its efforts to investigate the objective truth of claimed previous-life memories, contributes to documenting the Druze discourse on 'speaking.' Finally, cases of 'speaking' have recently been addressed from the perspective of false memories and memory distortion (see French, 2016).

\section{Taqammus}

According to the Druze notion of transmigration, the human body is tantamount to a 'shirt' (qamiss) that the soul ( $r \bar{u} h)$ wears. At the moment of death, the soul immediately ${ }^{8}$ puts on a new shirt,' that is, it instantly moves to a new body. ${ }^{9}$ Any individual soul thus passes through an infinite number of bodies in which it completes successive life-circuits. The sojourn of the soul in one particular body equals one life-circuit, and the moment it leaves that body for the next one a new life-circuit begins. In local parlance, these successive life-circuits are termed 'generations' (ajyāl; sg. $j i \bar{l})$.

As stated explicitly in Druze scriptures, the soul cannot be a part of the world without a body (see also Kastrinou, 2016: 65-67). In the terminology of the Kitāb an-nuqat wa-dawä 'ir, it 'manifests' (zahara) through the body and at the same time is 'hidden' by the body as the 'manifesting' entity; the body is the soul's 'veil' (hijāb) (see Seybold, 1902: 30-31). ${ }^{10}$ The notion of taqammus thus, on the one hand, focuses on the soul's movement from body to body, which implicitly relegates 
the body to something unessential and replaceable; on the other hand, a particular soul, which is essentially the same throughout all the life-circuits, is always a part of the world in the form of a distinct human being.

This article contends that, if one wishes to understand the ambivalence of the phenomenon of 'speaking,' then the involved human beings must be taken seriously. In this respect, Luc Boltanski's work on abortion (The Foetal Condition) offers important analytical tools (Boltanski, 2013: 27-59). According to Boltanski, a human being takes his or her place in society both because he or she has (1) membership within categories, and (2) a personal identity without any possibility of being confused with another, i.e., a human being is susceptible both to arrangement in classes and to singularization (Boltanski, 2013: 29). If, according to the Druze outlook, a soul transmigrates, it thus not only moves from manifesting as one human being, who has membership in different categories that grasp him or her at every turn to manifesting as another human being for whom holds true exactly the same, but it also moves from occupying one singular place in one familial group to occupying another singular place in (mostly) another familial group. Because each life-circuit of the soul is associated with a singular place in a familial group, the migration of the soul thus runs across the boundaries of individual Druze familial groups, and the conflicting logics of taqammus ('soul') and descent ('blood') produce the effect that people are 'born in each other's houses' (see Oppenheimer, 1980). ${ }^{11}$ Nonetheless, in each life-circuit, the soul manifests as a distinct human being, which belongs to some particular familial group, is loved by them, and so forth.

According to the Druze world-view, normally the soul does not remember its previous life - at least not to the extent that this would be reflected at the level of speech. ${ }^{12}$ The different families, in which the same soul has manifested in the form of a concrete human being, normally do not know each other. ${ }^{13}$ As long as this does not change, the notion of transmigration mainly raises questions concerning an individual's membership in his or her ethnic-religious and sex group. More specifically, a Druze soul is thought to move to a Druze body of the same sex (see Nigst, 2017). ${ }^{14}$ Against the backdrop of endogamy, this produces an important ideological and 
unifying effect of establishing the notion of a 'soul'-based form of relatedness for all members of the Druze collective (Armanet, 2011: 210-215). But what happens if children do remember a previous life and two singular places exert their pull?

\section{Porous boundaries}

According to the Druze world-view, the boundary of oblivion, which normally separates two lifecircuits of a soul, sometimes becomes porous and children start to 'speak.' It is common Druze knowledge that the phenomenon often starts off with protests on the part of the 'speaking' child about being misplaced (see Bennett, 1999: 88).

On the one hand, 'speaking' children are stated to reject their proper name, deny that their parents are really their parents, and claim that they are someone else. People tell about children who are upset, cry, or tell their families that they do not like them, often claiming that the house where they currently reside is not their house. Additionally, these children also often offer memories of how their own previous lives ended, such as a fatal accident, or providing even the name of the person who murdered them.

On the other hand, the feeling of being misplaced also concerns the categories in which the child is a member (see Nigst, 2017: 66). Most common in this context are the age categories (see Stevenson and Haraldsson 2003: 286), most likely because re-birth implies a return to the category of 'child' and regularly shifts previous-life 'adults' to present-life 'children. ${ }^{15}$ For example, interview partners sometimes state that 'speaking' children who passed away as adults find it annoying to be treated like children again. They reportedly protest against being forced to wear children's clothing or are furious about perceived unseemly treatment, such as being reprimanded in public (see Lațîf, 2014: 194). A recurring element in this context is the demand of 'speaking' children to see their previous-life husband or wife. Considering that many people who passed away were parents, it makes sense that 'speaking' children often want to 'see their

children.' Furthermore, cases often show something odd and decidedly 'un-childlike' about the way they speak; or the language they use and their tone ${ }^{16}$ suggests the child to be an adult (see 
also Lațiff, 2014: 265; 275). The notion of being in the presence of a child who is not really a child occurs: 'To me, he is an adult playing a child. ${ }^{17}$ Or: 'There is something older' than the child 'that is speaking' ( $f_{\imath}$ shī akbar minno 'am yihkī'). ${ }^{18}$ There are skills one would not expect from someone of their age ${ }^{19}$ and children who prefer being in the presence of adults. Not least, in this context, there are cases of inexplicable linguistic skills ('xenoglossy').

Misplacement and similar dissatisfaction furthermore may appear in respect to socioeconomic status, and the 'speaking' child may, for example, indicate that the present, lesser status does not befit him or her (see Abū Shaqrā, 2016). Misplacement in respect to ethnic-religious or confessional belonging and the sex or gender categories, however, is extremely rare or totally absent. Thus, despite sometimes being met with critique ${ }^{20}$ and despite more universalistic outlooks on taqammus, the idea is prevalent that Druze men are always reborn as Druze men, and Druze women as Druze women ('titqammaș min Dirzì la-Dirzì'), and the potentially subversive character of taqammus, as far as the ethnic-religious boundaries are concerned, is kept at a minimum, if not explicitly denied see Nigst, 2017: 63-64). ${ }^{21}$ This reflects the general Druze conviction that the Druze collective consists of the same souls that sincerely joined the Druze in the $11^{\text {th }}$ century AD (see Rivoal, 2000: 32). In fact, it seems that the idea that transmigration takes place in accordance with the ethnic-religious boundaries is challenged mostly at the discursive level and when individual people try to readjust taqammus with other convictions they may hold such as communism or a world-view oriented towards the natural sciences (see Nigst, 2017: 75). As regards the concrete cases that happen in one's own environment, they virtually all corroborate that Druze are reborn as Druze.

\section{When the unknown becomes potentially knowable}

While some people might interpret a child's 'speaking' as nonsense ('turrahāt'), others believe that it can open a window through which a previous life may find its way back into the present. Apart from explaining phobias or predilections, ${ }^{22}$ people do reckon with the possibility that the words of the child may actually lead back to the familial group with which his or her soul was previously associated, that is, the previous-life personal identity may become known. Thus 
possibly establishing relations between two otherwise unrelated families, ${ }^{23}$ instances of 'speaking' may have 'concrete social effects both on families and communities' (Bennett, 1999: 79). Analytically speaking, there are three degrees to which a 'speaking' child is allowed to break through to the level of concrete 'previous-life' people in the social world. First, the previous-life family may be met, and, contingent on proof, which includes both the child's ability to name the previous-life family members and particular episodic memories, the 'speaking' child may 'retake' his or her previous place. ${ }^{24}$ In this case, the soul indeed has moved on to a new unique place, but is allowed an additional space and context where everything is as if it had not and to which it 'returns' in different bodily form. This form of re-taking may translate into fulfilling relationships and mutual visits between present-life and previous-life families of the reborn individual, the involvement of him or her in rites (see e.g. Stemman, 2012: 34), and potentially he or she receiving 'inheritance' or financial support from the previous-life family. The extent to which that happens, if at all, varies and the resulting relationships may change over time. Second, 'speaking' may reach into the level of real people in the social world only to a lesser extent. One may, for example, know who the previous-life family are, but shy away from taking the final step and knock on their door. ${ }^{25}$ Third, efforts to thwart the relationship-forming force of 'speaking' before it takes any effect are common for dealing with the 'speaking' of a child.

According to our interview partners, whether an individual case of 'speaking' unfolds to a level where it involves 'previous-life' people may be due to a conscious effort or product of random circumstances; it may be wanted or not; it may be wanted by both families, or only one of them. Sometimes 'speaking' children give information specific enough to lead back to concrete human beings and families. It seems that some families of 'speaking' children make substantial efforts to identify the previous-life family of which their child 'speaks.' They keep asking around and their quest may lead them from village to village. Other times the family of the passed-away individual actively starts to look for cases of 'speaking' that could match their lost relative and visits the family of the 'speaking' child as soon as knowledge of his or her case has started to spread (Iklimos, 2012). Alternatively, children might stumble across their previous-life, or their 
previous-life relatives, by chance ( $\left.b i-s-s u d f e^{\prime}\right)^{26}$ - something which may also happen later in life. The latter is quite common and, according to our interview partners, this makes sense because the memories of a previous life are often sparked through the confrontation with things that either are from the old life or resemble it. ${ }^{27}$ 'Speaking' does not, however, necessarily lead to the establishment of a taqammus-based relation between two families. This may be due to circumstances or a conscious effort to thwart the relationship-forming potential of 'speaking.' On the one hand, the information may be too scarce or the names and places may not be able to be identified. Conversely, even if a matching passed-away individual is found, the family of that individual does not always show interest or the child fails to deliver 'proof.' On the other hand, the family of a 'speaking' child does not always tolerate possible efforts of bereaved families to reach out to the 'speaking' child. Lebanese Druze shaykh Sāmī Abī 1-Munā recommends that families should reject such efforts and drive away those who make them ('ishrabü finjān qahwa, Allāh ma'akum, khalāṣ'). ${ }^{28}$ As a final possibility, the family of the 'speaking' child does not always allow their child's 'speaking' to really unfold and it gets stalled before it may actually lead to concrete human beings of a previous life, and the previous life ideally disappears.

\section{The encroachment of another singular place}

Sociologically speaking, both the 'speaking' child and the passed-away individual, continued to be caught in a 'singularization process, ${ }^{29}$ which underlies his or her personal identity and allows him or her to be identified individually 'without any possibility of being confused with another' (Boltanski, 2013: 28-29). Initiated long before birth and 'involving conception, pregnancy, birth, integration into a social group and subsequent phases of socialization' (Boltanski, 2013: 20), this process enables the 'access, after birth, to a singular position in society' (Boltanski, 2013: 49), and it will be necessary to conduct careful research into how this process looks like in the Druze communities. Both were born into a respective singular position that 
awaited them before birth; both were 'taken up in a symbolic mode' and 'in speech' (see Boltanski, 2013: 37) - but not by the same people. Thus, if 'speaking' leads to the previous-life personal identity, the relation of a soul with its past factually takes on the form of a relation between two singular places in Druze social space, which by definition entails the perception that the soul, and thus the human being as which it currently manifests, not only is torn inside and struggles with accommodating the previous-life memories, but also is pulled into the direction of two different familial groups and personal identities.

Many people are worried that 'speaking' will thus expose the child to contradictions and inconsistencies ('tanāqud'). The affected individual threatens to 'become like two personalities' ( bișir mithl shakhșiyyatayn'), which is potentially detrimental to the psychological well-being of the 'speaking' child ('khațīr bi-nafsiyyit il-walad'). In the light of the potential appearance of the family in whose fold the soul manifested in its previous life, many people are afraid of the inner conflict of (objectively) competing belongings (see Bennett, 1999: 103). Allowing 'speaking' to pull towards the previous life is thus tantamount to accepting the inconsistencies and difficulties that come along with wanting to be 'here' and 'there' at the same time, which is not considered a good way of growing up ( harām tikbar hēk'). Even reborn people, who may find it positive that they went through a 'unique experience,' point to the inherent ambivalence of that experience. ${ }^{30}$ The situation furthermore may cause pain and hurt feelings, especially on the part of the presentlife family, which has to accept that the encroachment of the past may orientate their child towards an additional familial belonging ("You are not my mom!"). It is here that taqammuṣ is 'ugly and difficult' (bashi' $w$-șa ' $\left.b^{\prime}\right)$, as a reincarnated woman in Lebanon stated recalling her own experience. The previous-life family may have 'found' a lost family member again and be happy about that, but the present-life family may feel to have partially 'lost' their child. In fact, the human being, which in a concrete case of 'speaking' is pulled towards another family and who 
from an abstract perspective simply is a transient corporeal manifestation of a soul, is a loved human being who belongs to particular people. Although it may sometimes be desired that through 'speaking' one's own familial group establishes a relation with others, coming to terms in real-life with the consequences of one's own child having an additional belonging is not necessarily easy, and be it at the most trivial level such as disagreement about who picks up the child from school. As a young Syrian refugee now living in Germany explained: 'A family always loves its child, and they want it to belong only to them - and not to two families.' According to him, especially the present-life mothers are distressed by the pull of the previous-life world on their child ('da 'iman il-imm bithibb tifla'), which may lead to the feeling that the own child has become someone else's child (see Dwairy, 2006: 35) and to substantial animosities (see Iklimos, 2012). Ambivalent feelings may develop even in cases where the previous-life and the present family are on good terms and where the parents encouraged the 'speaking' of their child and the identification of the previous-life family. Significantly, the impression occurs that the previouslife family is 'stealing' the child (see Dwairy, 2006: 44).

Moreover, despite allowing the 'return' of a person lost to death in different bodily form, the previous-life family may prefer if the singular position of their passed-away relative was not retaken.' They may be afraid that they might have to give financial support to the 'speaking' child and his or her family. Even in cases where a 'speaking' individual is recognised, reluctance to support the 'speaking' child financially may show, and it may be rationalised, for example, by pointing to previous-life greediness. Unpleasant secrets may surface. ${ }^{31}$ Maybe a different body simply cannot be accepted for the passed-away relative. Conversely, the reborn individual might not want to bear the responsibilities that come along with the previous-life place. For example, a young man from Deir al-Qamar in Lebanon explained to us that he was afraid of such responsibilties. This is particularly relevant if reborn individuals by chance stumble across their previous life in adulthood again. Generally, fears of having to fulfil social obligations seem to be playing an important role in the context of cases of 'speaking' (see Bennett 1999: 108). Not least, individuals maybe later in life develop the feeling that the space of their lived body - their 'private 
sphere' - is being encroached upon and would have preferred to be associated only with their present life. Illustrative in this respect, one of our Lebanese interview partners who died from cancer in her early twenties in her previous life, told that her previous-life mother was extremely happy about having re-found her dearly loved daughter whose premature death she was still mourning. Yet, our interview partner was emphatically not entirely happy about the same situation, indicating that she for the most part had stopped visiting her previous-life mother because seeing her was like returning to all of the sadness over and over again, and it implied meeting with someone who always wanted to hug and squeeze her; who was caught in the past while life had moved on.

Thus, in particular if the previous-life family recognizes the 'speaking' child, the resulting sociologically real relations may be difficult, not least emotionally. Two processes of singularization objectively clash and pull into opposite directions and direct the child towards different places and towards different names. Hence, as a notable shaykh puts it, to really let an individual case of 'speaking' unfold its full force is tantamount to entering a 'gigantic maze' ( matāha tawìla 'arìda'). ${ }^{32}$ Whoever is willing to let that happen, risks not only that the respective individual gets lost between two lives and the pull of two different belongings ( biḍ̂̄' il-walad;' ‘ bi ish bi-d-day $\left.\bar{a}^{\prime \prime}\right)$, but also exposes everyone else involved in the case to the (emotional) dynamics of conflicting singular positions and the social obligations that come along with them.

\section{Hierarchies}

According to many interview partners, the previous-life and the present life should not be placed at the same level. The soul has 'moved on,' and it is the present life, which has priority. Significantly, they insisted that the 'real' name of the 'speaking' child is the name that pertains to the present life, while the previous-life name at most could be regarded and used like a 'nickname' (laqab). Evidently, the previous-life human being and the present-life human being are not simply the same. Our interview partners express this thought in a variety of ways, mostly referring to someone's 'old person' and 'new person.' It is in the new person that someone lives. They 
explained that despite having memories of a previous life as someone else, the respective individual 'thinks in a new way.' This means that the previous-life memories are, or increasingly become, only a part of the self of the person involved, which in his or her present life relates to the world in new ways, making new memories and experiences. Lexemes pertaining to the semantic field of 'thinking' were used to express this relative autonomy of the present life. Different of our interview partners repeatedly stated that someone lived with a 'new mind' or a 'new brain;' that the person's 'thinking' was different.

As an older Syrian refugee currently living in the Austrian countryside explained, the parents of the 'speaking' child clearly have the responsibility to avert the encroachment of the previous life on the present life of their child. This was tantamount to 'protecting' the life of the child ('hārisin hayāto') so that he or she could grow up 'undamaged' and 'sound' ('salìm'). According to him, the parents best prevented the previous-life personal identity, which threatens to reappear, from meddling with this present life, and shielded their child from being dragged into an alternative and competing form of belonging that has had its time (see Nigst, 2017: 76-77). 'Silencing' the child, or trying to make sure that the memories do not end up establishing a conflicting form of belonging, seem to fulfil this function.

\section{'Silencing' the 'speaking' child}

It is plausible that people who are afraid of the negative consequences of a particular type of speech make an effort to turn that speech into silence: Over and over again, our interview partners mentioned that 'speaking' children were 'silenced' (sakkata; mana 'a min al-kalām) by their parents. ${ }^{33}$ The pairs 'to remember' (tadhakkara) / 'to make forget' (ansā) on the one hand, and 'to speak' (națaqa) / 'to silence' (sakkata) on the other hand, are part of almost every conversation about the phenomenon of 'speaking' children. ${ }^{34}$ 'Silencing' the 'speaking' child obviously 
corresponds to the effort of containing him or her in the boundaries of his or her present-life personal identity and of 'deafening' him or her vis-à-vis the voices of the past ('bitarrshu').

This strong presence of 'silencing' is a good reminder that, emically speaking, nutq is not matter of choice - it just happens. This is not to say that Druze people themselves dismiss entirely the idea that nutq could be 'fabricated' and the child enticed into 'speaking.' On the contrary, they address not only the fact of 'speaking' (națaqa), but also the fact of 'being made to speak' (nattaqa) (see also Bennett, 1999: 106-107). ${ }^{35}$ But ruling out the latter possibility, which might be true in some cases, 'speaking' is understood to be something that simply washes over people without them having a say. They can react differently to an instance of 'speaking,' but the fact that it occurs, is beyond the grasp of their will. In fact, many people abhor the idea of remembering a previous life. They are convinced that the memories of the previous life are real, but they would do everything they can in order to prevent them from gaining any momentum. As a young Syrian refugee in Austria explained: 'If I had a child in the future who started to speak about a previous life, I would at once try to make him or her forget.' According to what people say, it is, however, not always possible or easy to make a child forget. 'Speaking' children especially become vengeful ('nāqim') and difficult ('mashkaljī') when they feel resistance from their parents, and their subjective yearning for a previous place is met with unsuccessful efforts at making that yearning go away. Although some of our interview partners were quite stoic and insinuated that the situation resulting from the concrete cases was 'no big scandal' (' $r a w \bar{a} q$ '), people's frequent emphasis that 'silencing' the children maybe was the best choice, seems to suggest that they reckon with problems and conflict in this context. Many people insist that forgetting is necessary

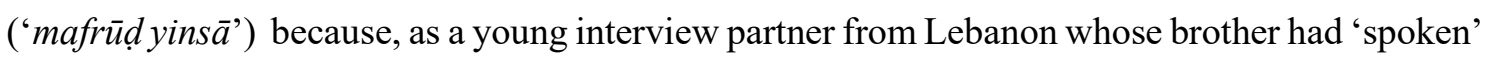
explained, people 'cannot not live two lives at the same time' The result would be confusion, and many families do not want the feeling of being 'torn between two families' (Dwairy, 2006: 40). Clearly, the decision to 'silence' a 'speaking' child may often also be motivated by the wish to have a child that behaves in an age-adequate manner. As one young Syrian interview partner 
explained, people do not want to have a 'child who is not a child at the same time' ( Iifl huwa mush tifl'). Remembering their adult selves, the affected children allegedly may not only feel belittled because of having suffered the loss of the social standing and respect accorded to adults, but also the "normal' hierarchies between children and adults may end up turned upside down under some circumstances. For example, one Syrian refugee in his mid-fifties, who now lives in Vienna, told the case of a 'speaking' boy who in his previous life was a famous Lebanese shaykh. When he was a pubescent boy, people started to pay pious visits to him, which placed him in a considerable position of power, with the social roles of him and his father being turned upside down. Not least, it may be difficult to come to terms with the fact that, all of the sudden, for example a 'boy' is the 'husband' or 'man' when, according to the social construction of masculinity, a 'boy' is the exact opposite of a 'man.'

\section{Emerging and disappearing}

According to our interview partners, the pull of the singular position of the former life is not necessarily constant because that position essentially has its importance and force based on the child remembering his or her previous life. As the child grows more familiar with his or her present life ( bișir yit'aqlam ijbārì') and develops emotional ties with the new family ( $y i k u \bar{u}$ yit 'alla' bi- 'ayle jdìde'), those memories may fade away, with the wish to return to the previous life lessening or disappearing entirely. In fact, Druze discourse usually starts from the assumption that for a period the soul misses the previous life, which it had in a different body (see Armanet, 2011: 151-152). However, after a while it starts to feel 'at home' in its new place. As has been emphasised, this place is not just a body, but also a singular position in a family. As a result, what according to Druze discourse corresponds to the process of the soul growing familiar with its new place and its losing interest in returning to the previous place, in real life translates into 'speaking' children who emerge in another familial context, but maybe also disappear from it again (see Nigst, 2017: 77). 


\section{'Speaking' and the contingency of one's own world-view}

The Druze claim that all human souls migrate, should also entail cases of 'speaking' that occur among their non-Druze or atheist neighbours. However, these types of cases are minimal, and the Druze are aware of that. ${ }^{36}$ In dealing with this particular form of contingency rooted in the factual plurality of alternative world-views (Von Stosch, 2003: 25-30), not only does wider Druze discourse turn to 'worldwide evidence of reincarnation,' but more specifically interview partners suggest that cases of 'speaking' do occur among their non-Druze or unbelieving neighbours. Those families, however, instantly suppress or quench the 'speaking' under way ( "amaliyyat annuṭq tuqma 'min huwa zghīr'). One Syrian interview partner who fled to Austria with her husband told about her Christian friend whose son started to talk of a previous-life as soon as he could speak. The Christian friend told her that she did not let her son 'speak'and that she made sure that he forgot about it ( 'nassìtu l-mawdiu'). The idea that non-Druze quench 'speaking' is significant insofar as it leaves virtually no room for the idea that taqammus / nutq does not exist. If nonDruze quench the words of their 'speaking' children, they are not relegating them to the realm of fantasy, but are making go away what must not exist according to their dogma. The contingency of one's own belief is thus mitigated by observing that the others may say that taqammus / nutq does not exist, but the things they go through and do suggest otherwise. Alternatively, many Druze emphasise that ethnic-religious groups, which do not believe in taqammus, do not pay attention to the 'speaking' of their children; ${ }^{37}$ they 'do not take it seriously.' It is precisely for this reason that the concrete cases are so important where 'speaking' children prove in often perplexing ways that their claims are true. Not only are they the moments where taqammus becomes 'palpable and real' for the Druze themselves, but they are also the moments where members of ethnic-religious groups whose dogma rejects taqammus or even atheists (mulhid) 'cannot deny taqammus anymore' ('mā 'andon il-qudra la-yinfü l-mawdiù'), as a young Syrian refugee now studying in Germany explained. Concrete cases of 'speaking' that unfold in front of their eyes are something they (e.g. Christians) have 'experienced and seen' ( 'āshu hādhā sh-shī wi-shâfūhu'). It seems 
that, when confronted with the experience of concrete cases of nutq, the religious others are sometimes even forced to re-adjust their own beliefs (or at least admit that an understanding of reality other than their own is possible). They may even be forced to say that taqammus is true and not just do things that suggest they believe. Statements of our Syrian interview partners regarding the 'quenched' 'speaking' of the children of their Christian neighbours probably genuinely reflect a situation of confessional or ethnic-religious plurality. They most certainly suit one's own world-view and thus help take off the edge of the contingency that results from ethnicreligious plurality. But in contradistinction to fundamentalist or extremist forms of 'religion' where contingency is sought to be eradicated (see Von Stosch, 2003: 34) it is part of a world which, to a certain extent, is shared in common.

\section{Conclusion}

Buttressing internal coherence and suggesting that the world is just, the Druze perception that Druze souls migrate according to a divine logic within the limits of their own ethnic-religious group seems beneficial. Considering the body only a transient manifestation of a soul, the perception that souls transmigrate moreover may encourage a philosophical stance that considers the individual body as only a transient manifestation of an eternal soul, from which one best disengages, and with regard to which one recognises that it is a mere 'veil' that replaced, and will be replaced, by other 'veils.' It makes sense, however, that such disengagement is more difficult the moment people are not reflecting on 'souls' and 'bodies' in abstract fashion, but the 'body' in question is a loved human being that belongs specifically to them. Precisely in this context, cases of 'speaking' are interesting. They certainly corroborate the claim that souls migrate in palpable fashion, communicate all sorts of moral lessons, and allow establishing relationships that could otherwise not have been established. Nonetheless, a 'pervasive ambivalence' (Bennett, 1999: 92) that is mirrored in Druze discourse seems to remain with regard to the phenomenon. As a woman from Lebanon put it, recalling her own 'speaking,' the phenomenon was 'nice and not so nice at the same time' ('helu mush helu') - there always is what 'lifts the heart and what makes one cry' (Iklimos, 2012). This ambivalence is interesting because it relativises the Druze dismissal of the 
importance of the body as well as their insistence that death does not really matter and 'has no dominion' (Maher, 2014) in their communities. On the one hand, 'speaking' allows the 'return' of someone lost to death in different bodily form; on the other hand, not only the need for the 'return,' which mostly seems to occur when unexpected death rips out loved ones "too soon" and makes the ugly (bashi ${ }^{\circ}$ ) and unjust disappearance of a human being especially difficult to bear, ${ }^{38}$ but also the anticipation of difficulties and the efforts of avoiding them through 'silencing' 'speaking' children point to the relevance of the singular human beings who the manifestations of a soul de facto are. In the context of 'speaking,' there are different, and often beautiful, ways for the Druze to handle the social, emotional, and continuing reality of those singular human beings. However, all of them engage the notion of a soul that objectively has moved on to a new life, yet subjectively still yearns for its former place in the world, from which it had no time to disengage, and seems to have its peculiar forms of agency.

\section{Funding}

Austrian Science Fund (FWF): Stand-alone project P28736.

\section{Acknowledgement}

I would like to thank my colleagues Gebhard Fartacek, Gerda Lechleitner, and Daniel Mahoney as well as the anonymous peer reviewers for their advice.

\footnotetext{
${ }^{1}$ As against other self-referent terms such as Muwahhidūn or Banū ma 'rüf, the designation Druze is used here because of its sheer prevalence.

${ }^{2}$ Mutaqammiṣ / nātiq (masc.) and mutaqammișa / nātiqa (fem.) in local parlance.

${ }^{3}$ See Bennett (2006); Ṭalī' (2001: 19; 113).

${ }^{4}$ See e.g. https://www.youtube.com/watch?v=XGN-TgQ-0iM (accessed 4 July 2017; min 52:50 ff).

${ }^{5}$ One interview partner told the story about two men A and B. Individual A fathered a child C. B killed A. B was killed by someone else and was reborn as D, the son of C. D started to 'speak,' resulting in the revelation that $\mathrm{D}$ killed his grandfather $\mathrm{A}$ when he was $\mathrm{B}$. The two families involved could not but admit that speaking in terms of 'them' and 'us' did no longer make any sense.
} 
${ }^{6}$ The interviews were conducted by my colleague Gebhard Fartacek and myself as well as by Amjad Khabboura.

${ }^{7}$ We were able to talk to parents of 'speaking' children in Israel in August 2017.

${ }^{8}$ Druze often claim that the final breath of a dying person is the first breath of the newborn to which the soul moves.

${ }^{9}$ This is expressed by the Arabic verb taqammașa of which taqammus is the verbal noun.

${ }^{10}$ Albeit denying previous-life memories, the K. an-nuqat wa-d-dawä 'ir by Zayn ad-dīn 'Abdalghaffār (d. $1557 \mathrm{AD}$ ) is an insightful source in respect to transmigration. Systematizing and elaborating on the thoughts found in the Rasa 'il al-hikma, it not only speculates about how the individual souls come into being, but also highlights the idea central to the Druze understanding of taqammus that the soul is always in need of a body. Apart from broaching other themes of importance to the wider Druze discourse on taqammuș (e.g. present suffering of children as proof for previous lives), the work is regularly cited by Druze authors because of its intellectual value. For the work, see Firro, 2011.

${ }^{11}$ In the context of the pain caused by having to leave one's house, compare the analogy between 'soul' and 'bride' (Armanet, 2011: 248).

${ }^{12}$ According to our interview partners, seemingly unmotivated laughing and crying of newborn children is best explained by memories of a previous life (see also Armanet, 2011: 152).

${ }^{13}$ Not least, this is reflected in an ascetic ideal that involves a conscious and voluntary detachment from the own familial group. As stated by Oppenheimer (1980: 627) in respect to old religious Druze, '... since it is expected that rebirth will probably be into another patrilineal group, and possibly into a distant village, it is appropriate as death draws near that they should disengage themselves from the particular household and lineage with which they have been associated in their current lifetime.'

${ }^{14}$ A remarkable objectification of the membership within these categories is found in a Druze cemetery in Pekiin in Galilee where there are two separate chambers for 'male' and 'female' Druze. For the notion that the collective Druze burial chambers generally reflect the unity caused by transmigration, see also https://www.youtube.com/watch?v=XdcVuEE6g18 (accessed 12 October 2017; min 26:25 ff).

${ }^{15}$ The Druze receive newborn children as if they were adults (see Armanet, 2011: 151).

${ }^{16}$ As interview partners stated, they talk to adults 'as if they were their fathers or mothers;' they are 'four years old, but behave as if they were thirty.'

${ }^{17}$ See https://www.youtube.com/watch?v=0_v2Pb9jopo (accessed 19 May 2017; min 35:00 ff.).

${ }^{18}$ See https://www.youtube.com/watch?v=0_v2Pb9jopo (accessed 19 May 2017; $\min 48: 50$ ). 
${ }^{19}$ A recurring topos is that children know how to handle a machine (e.g. an airplane) or have knowledge of highly specific vocabulary.

${ }^{20}$ Some young Syrian interview partners with tertiary education associated the idea that Druze are reborn as Druze with the notion of 'simplicity' and 'lack of education' ( 'in-nās il-busața '); with religious beliefs that were not the result of the study of the religious texts, but knowledge from hearsay ('illi akhadhi $d$-dinn mithl mā sama 'ühu bass').

${ }^{21}$ There are cases, however (see Lațîf, 2014: 266-270); see https://www.youtube.com/watch?v=XGNTgQ-0iM (accessed 4 July 2017).

${ }^{22}$ For example, someone who drowned in his or her previous life might be afraid of water, or someone who died in a car accident might be afraid of reckless driving (Lațif, 2014: 274). As regards predilections, interview partners explained, for example, that they were vegetarian or preferred to wear their hair long with their previous life. Another interview partner reported about a young man who used to be a farmer in his previous life and who still had a penchant for the typical pastimes of farmers from earlier generations ('ando shī min zamān') instead of engaging in the typical pastimes of his generation ('football, Facebook').

${ }^{23}$ For this point, see also Bennett (1999: 10). If 'speaking' happens within the same family, according to our interview partners, the pair 'grandfather' and 'grandson' is frequent.

${ }^{24}$ The important issue of proof is beyond the scope of this article (see Nigst, 2017; French, 2017: 90-91).

${ }^{25}$ One of our interview partners had discovered by chance his previous-life house later in his life (having 'spoken' as a child, his 'speaking' had not led to the previous-life family). More than once, he approached that house and fled as soon as he could have spoken with someone from his previous-life family.

${ }^{26}$ One interview partner told the story of his younger brother who went to the market with his mother and suddenly cried out because he spotted his previous-life mother in the crowd. He got out of the car and ran towards her. Another interview partner recalled playing outside, when she by chance spotted her previouslife mother and detected a picture of herself hanging on the wall of her previous-life home.

${ }^{27}$ Our interview partners mentioned that, some people this way stumbled upon their own murderer.

${ }^{28}$ See https://www.youtube.com/watch?v=XGN-TgQ-0iM (accessed 6 June 2017).

${ }^{29}$ For the thematic of singularity, see Boltanski (2013: 29-49).

${ }^{30}$ See https://www.youtube.com/watch?v=XGN-TgQ-0iM (accessed 9 June 2017); min 13:55 ff.

${ }^{31}$ One interview partner from Lebanon told how she brought to light an affair her previous-life father had had.

${ }^{32}$ See https://www.youtube.com/watch?v=XGN-TgQ-0iM (accessed 6 June 2017). 
${ }^{33}$ See Bennett (1999: 88); Dwairy (2006: 40); see also Lațîf (2014: 267). The motives for a particular family to 'silence' a child are not necessarily clear, however. One young interview partner from Syria asked his mother later in his life why she did not let him 'speak' when he was young. She told him that he said names, which were unknown to the family and they had no idea where to look for those people. As the interview partner suggests, discussions with his grandmother, on the other hand, insinuated that his mother was not entirely honest and that the previous-life family indeed may have been known.

${ }^{34}$ Considering that the initial contact with the previous life often occurs 'by chance,' some interview partners ruled out the possibility of making a child forget the previous life for good because incidental contact with previous-life things or people would instantly trigger the memories. For example, one interview partner who was 'silenced' by his parents in his childhood, at a later point in his life listened to a tape with music that instantly transported him back to his old life when he instantly knew that there was something 'missing.' Other interview partners were more optimistic in regards to the possibility of making a child to forget for good.

${ }^{35}$ The point is unclear, but people occasionally indicate that children are 'talked into' memories, and that there are parents who actively help the child in 'speaking.'

${ }^{36}$ I am thankful to Jim Tucker (University of Virginia, School of Medicine) for the information that out of the 151 Lebanese reincarnation-cases in the database of his research institution, 19 concern non-Druze individuals. (Email, 15 November 2016).

${ }^{37}$ For a case involving a Christian Lebanese girl where the family's rejection of the belief in taqammus led them to not being responsive to their daughter's memories, see Lațîf (2014: 267). Similarly, one Christian interview partner in Lebanon stated that Christians did not believe in taqammuṣ and thus paid no attention to the 'speaking' of their children.

${ }^{38}$ The unnatural death ( 'mush tabi 'i ') in question cannot be considered to be replicating a prototype (i.e. the 'natural' death) and does not constitute part of the types of death with which are to be 'reckoned' (see Bloch and Parry 1982: 15; Rivoal 2000: 350-355). 


\section{References}

Abū Shaqrā S (2016): Tuwuffiya Wā' il fī sinn ath-thamāniya wa-l-arba 'īn wa- āda ilā l-ḥayāt liyabhath 'an 'à'ilatihī. An-Nahār, 8 June. Available at: www.annahar.com/article/395204 (accessed 29 November 2016).

Armanet E (2011) Le ferment et la grâce: Une ethnographie du sacré chez les Druzes d'Israël. Toulouse: Universitaires du Mirail.

Bennett A (1999) Reincarnation, Marriage, and Memory: Negotiating Sectarian Identity among the Druze of Syria. Dissertation, University of Arizona, USA.

Bennett A (2006) Reincarnation, Sect Unity and Identity among the Druze. Ethnology 45 (2): 87104.

Bloch M and Parry J (1982) Death and the Regeneration of Life. Cambridge et al.: Cambridge University Press.

Boltanski L (2013) The Foetal Condition. A Sociology of Engendering and Abortion. Cambridge and Malden: Polity Press.

Bourdieu P and Wacquant LJD (1992) An Invitation to Reflexive Sociology. Chicago and London: The University of Chicago Press.

De Smet D (2007) Les Épîtres sacrées des Druzes: Rasā'il al-Hikma, vols. 1 et 2, Introduction, édition critique et traduction annotéedes traités attribués à Hamza b. 'Alī et Ismà îl at-Tamìmì. Leuven, Peeters.

Dwairy M (2006) The Psychological function of reincarnation among Druze in Israel. Culture, Medicine and Psychiatry 30: 29-53.

Firro K (2011) The Druze Faith: Origin, Development and Interpretation. Arabica 58: 76-99.

French CC (2016) Reincarnation Claims. In: Groome D and Roberts R (eds)Parapsychology: The Science of Unusual Experience. London: Psychology Press, 82-95.

Iklimos N (2012) Mātat wa-ba'd 30 'āman 'ādat tabḥath 'an Laylā wa-Māhir. Al-Joumhouria, 23 July. Available at: http://www.aljoumhouria.com/pages/view/19492/2799 (accessed 19 May 2017). 
Kastrinou M (2016) Power, sect and state in Syria: The politics of marriage and identity amongst the Druze. London: IB Tauris and Co Ltd.

Lațīf LI (2014) At-Taqammuṣ wa-tadhakkur al-hayāt as-sābiqa: intiqāl al-rūh am adh-dhākira? Bayrūt: Lațîf Ilyās Lațîf.

Maher J (2014) Death has no Dominion in Druze Life. In: John Maher. Available at: http://johnmaherwriter.com/wordpress/?p=734 (accessed 17 March 2017).

Nigst L (2017) Being One and Two and Druze: Problems of Belonging in the Remembrance of Previous Lives. Jahrbuch des Phonogrammarchivs 8: 58-81 (forthcoming).

Oppenheimer JWS (1980) 'We Are Born in Each Other' Houses:' Communal and Patrilineal Ideologies in Druze Village Religion and Social Structure. American Ethnologist 7(4): 621-636.

Rivoal I (2000) Le maîtres du secret: Ordre mondain et ordre religieux dans la communauté druze en Israël. Paris: Éditions de l'École des Hautes Études en Sciences Sociales.

Rivoal I (2016) Druzes de la montagne libanaise. Monographie originale présentée en vue de 1'Habilitation à Diriger des Recherches. Vol. 2 / 3. Paris: Université Paris Ouest Nanterre la Défense.

Seybold C (1902) Die Drusenschrift: Kitāb Alnoqaț Waldawāir. Das Buch der Punkte und Kreise. Leipzig: Kirchhain N.-L.

Stemman R (2012) The Big Book of Reincarnation. Examining the Evidence That We Have All Lived Before. San Antonio: Hierophant Publishing.

Stevenson I and Haraldsson E (2003) The Similarity of Features of Reincarnation Type Cases over Many Years: A Third Study. Journal of Scientific Exploration 17 (2): 283289.

Țalī`A (2001) At-Taqammuș. Buq āta: Ma rị̣ ash-shūf ad-dā’ im li-1-kitāb.

Von Stosch K (2003) Was sind religiöse Überzeugungen? In: Hans Joas (ed) Was sind religiöse Überzeugungen? Mit Beiträgen von Thomas Schärtl, Clemens Sedmak und Klaus von Stosch. Göttingen: Wallenstein Verlag, 103-146. 


\section{Author Biography}

Lorenz NIGST is a postdoctoral researcher at the Phonogrammarchiv of the Austrian Academy of Sciences in Vienna.

Address: Liebiggasse 5, 1010 Vienna, Austria.

Email: lorenz.nigst@oeaw.ac.at 